Abstracta Iranica Abstracta Iranica

Revue bibliographique pour le domaine irano-aryen

Volume 31 | 2011

Comptes rendus des publications de 2008

\title{
Friends of God: Islamic Images of Piety, Commitment, and Servanthood. Berkeley \& Los Angeles, University of California Press, 2008, 346 p.
}

Ève Feuillebois-Piérunek

\section{(2) OpenEdition \\ 1 Journals}

Édition électronique

URL : http://journals.openedition.org/abstractairanica/39725

DOI : 10.4000/abstractairanica.39725

ISSN : 1961-960X

Éditeur :

CNRS (UMR 7528 Mondes iraniens et indiens), Éditions de l'IFRI

\section{Édition imprimée}

Date de publication : 15 mai 2011

ISSN : 0240-8910

\section{Référence électronique}

Ève Feuillebois-Piérunek, «Friends of God: Islamic Images of Piety, Commitment, and Servanthood. Berkeley \& Los Angeles, University of California Press, 2008, 346 p. », Abstracta Iranica [En ligne], Volume 31 | 2011, document 246, mis en ligne le 11 octobre 2012, consulté le 02 octobre 2020. URL http://journals.openedition.org/abstractairanica/39725; DOI : https://doi.org/10.4000/ abstractairanica.39725

Ce document a été généré automatiquement le 2 octobre 2020.

Tous droits réservés 


\title{
Friends of God: Islamic Images of Piety, Commitment, and Servanthood. Berkeley \& Los Angeles, University of California Press, 2008, 346 p.
}

\author{
Ève Feuillebois-Piérunek
}

1 L'introduction survole l'hagiographie islamique dans sa variété. La première partie analyse les récits des moments-clés de la vie des saints: la naissance et l'enfance, souvent teintées de merveilleux (chap. 1), la conversion (chap.2) qui influence durablement la relation du mystique à son Dieu en le favorisant de rêves, visions, voix et visites surnaturels (chap. 3), les miracles (chap. 4), et enfin la mort (chap. 5).

2 La seconde partie s'efforce de replacer ces vies dans leur contexte social, institutionnel, culturel, en étudiant leurs interactions avec leurs sociétés et leurs communautés (exemples spirituels, défenseurs des faibles, guerriers, missionnaires ou marginaux) (chap. 6), leur rôle dans la création ou le développement de différentes institutions sociales et religieuses, en particulier les confréries soufies (chap. 7), leurs liens avec les lieux saints et la dévotion qui s'attache à leurs sépultures (chap. 8), l'exemple moral et spirituel que les saints constituent encore aujourd'hui pour des millions de musulmans (chap. 9).

3 La troisième partie s'intéresse à la forme et aux implications de ces récits. L'A. étudie les principales formes littéraires liées à l'hagiographie et dévoile leurs fonctions et la manière dont elles ont été utilisées par leurs auteurs (chap. 10). Il analyse également les dimensions théologiques, cosmologiques et psychologiques de ces contes en montrant comment les théoriciens musulmans ont analysé des thèmes comme la nature de la sainteté, le miracle, l'intercession, la vision et le rêve, donnant ainsi les bases théoriques nécessaires pour interpréter correctement ces récits (chap. 11).

4 Ce livre passionnant et bien documenté s'appuie sur de nombreuses sources du VIII ${ }^{\mathrm{e}}$ au $\mathrm{XX}^{\mathrm{e}}$ s. et du Maroc à la Malaisie, avec une prédilection pour le Mémorial des Saints de 'Ațtāar. Il est illustré d'une trentaine de reproductions de miniatures représentant des 
épisodes de la vie des prophètes et des saints, mais ne comporte malheureusement pas de bibliographie.

INDEX

Thèmes : 8 . Soufisme

\section{AUTEURS}

\section{ÈVE FEUILLEBOIS-PIÉRUNEK}

Université Sorbonne Nouvelle - Paris 3 - Mondes iranien et indien 